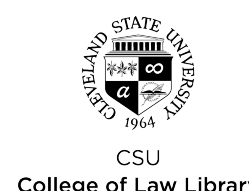

Cleveland State University

College of Law Library

\title{
EngagedScholarship@CSU
}

$1-15-2016$

\section{Language Control, 'Hyper-Sensitivity' and the Death of True Liberalism}

David R. Barnhizer

Cleveland State University, d.barnhizer@csuohio.edu

Follow this and additional works at: https://engagedscholarship.csuohio.edu/fac_articles

Part of the Law Commons

How does access to this work benefit you? Let us know!

\section{Repository Citation}

Barnhizer, David R., "Language Control, 'Hyper-Sensitivity' and the Death of True Liberalism" (2016). Law Faculty Articles and Essays. 820.

https://engagedscholarship.csuohio.edu/fac_articles/820

This Article is brought to you for free and open access by the Faculty Scholarship at EngagedScholarship@CSU. It has been accepted for inclusion in Law Faculty Articles and Essays by an authorized administrator of EngagedScholarship@CSU. For more information, please contact research.services@law.csuohio.edu. 


\section{CLEVELAND-MARSHALL COLLEGE OF LAW}

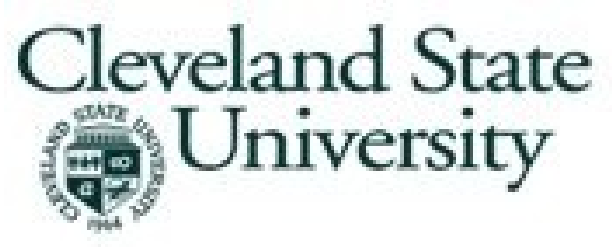

Research Paper 16-293

January 2016

\section{Language Control, "Hyper-Sensitivity” and the Death of True Liberalism by}

\section{David Barnhizer}

Professor Emeritus of Law, Cleveland-Marshall College of Law

Working Paper

This paper can be downloaded without charge from the Social Science Research Network electronic library: 


\section{Language Control, "Hyper-Sensitivity” and the Death of True Liberalism}

\section{David Barnhizer}

The Rule of Law in America is buttressed by the idea of free speech. Universities are supposed to be centers of free speech, dialogue and learning, in the process educating and preparing students to protect and preserve the unique ideal of the Western version of the Rule of Law. This includes the importance of competing factions attempting to achieve compromise through political discourse. There is a rather significant problem, therefore, when the dynamic and often contentious interactions that produce the ability to recognize the potential legitimacy of others' arguments and the flaws in one's own are short circuited by political agendas that punish speech rather than engage in true discourse. In that situation, the ability and willingness to hold onto such ideals as are inherent in the Rule of Law are being irreversibly damaged.

Consider, for example, the words of the late feminist scholar Mary Joe Frug. She wrote: "The liberal equality doctrine is often understood as an engine of liberation with respect to sex-specific rules. This imagery suggests the repressive function of law, a function that feminists have inventively sought to appropriate and exploit through critical scholarship, litigation, and legislative campaigns." 1 Appropriation of language and the ability to control others' language while denying them their own intellectual "safe space" is part of a deliberate strategy. While I may share some of the concerns of those seeking such control I am also deeply concerned about the effects such strategies have on the soul and integrity of the university in Western society. I have written about that mission in previous works. ${ }^{2}$

My fear is that the mission of the university is being altered and in some instances undermined by the heightened sensitivity of feelings among students, faculty and administrators who seem to be hurt or offended by almost anything. While the sensitivity may be real, imagined, part of an aggressive "mob mentality" or faked as a political ploy the "appropriation" and linguistic control movement is remarkable in its scope and import. The truth is that rather than being a legitimate educational strategy in too many instances what is occurring is a ploy to gain and exercise power through the control of language and the ability to accuse others of treating one "insensitively".

\footnotetext{
${ }^{1}$ Frug, "A Postmodern Feminist Legal Manifesto,".

2 See, e.g., "A Chilling of Discourse," 50 St. Louis University L. J. 361 (2006); "Truth or Consequences in Legal Scholarship," 33 Hofstra Law Review 1203 (2005); "The Revolution in American Law Schools," 37 Cleveland St. L. Rev. 227 (1989); "The Purposes and Methods of American Legal Education", 36 Journal of the Legal Profession 1 (2012);

"The University Ideal and the American Law School," 42 Rutgers L. Rev. 109 (1989); "Freedom to Do What? Institutional Neutrality, Academic Freedom and Academic Responsibility," 43 J. Legal. Ed. 346 (1993); "The Justice Mission of American Law Schools," 40 Cleveland St. L. Rev. 285 (1992); "The Purposes of the University in the First Quarter of the Twenty-first Century," 22 Seton Hall L. Rev. 1124 (1992); "The University Ideal and Clinical Legal Education," 35 New York L.J. 87 (1990).
} 
There are numerous valid reasons to criticize the institutions of a society. One certainly involves the question whether an institution is operating with inappropriate bias against individuals or identity groups. Educational institutions are among the most important mechanisms through which we create opportunities for advancement, and are supposed to produce people with the set of intellectual and other skills needed to function effectively in society.

An important part of the strategy employed by identity groups of late has been the invention of what are referred to as "micro-aggressions". Those are interactions in which feelings are hurt and students or other activists offended apparently to the point of fear, terror or paralysis. In this alternate universe those sensing the microaggressions demand punishment be levied against whoever made them "feel bad" or "scared" or "offended". Another element is the requested avoidance of "triggers" in teaching and other contexts in which a student or individual who has experienced some emotionally or physically traumatic condition in life needs to be forewarned about the possibility of a teacher discussing a topic, including a particular fact pattern in class discussions or on an exam, watching a movie with a topic that the teacher could or should have known or suspected might cause emotional pain related to "reliving" the experience, or not introducing controversial ideas that could challenge students' preferred preconceptions.

“Appropriating” and “controlling” is political activism voiced as linguistic control. But the strategy to control language and free expression has been taking place without much thought about its consequences both as a process and if it is fully achieved. There needs to be much more thought given to the implications of a strategy to "design" a new version of humanity and social organization through application of linguistic "governors" that increasingly dictate awareness and acceptable behavior in an information and language-based culture. ${ }^{3}$

John Gardner has described the problem with the kinds of position taking John Silber once warned were "epistemologies". He explained: "Of course, every line of behavior has its pathology, and there is pathology of dedication. People sometimes commit themselves to vicious or criminal goals. Or their commitment to worthy goals becomes so fanatical that they destroy as much as they create. And there is the "true believer" who surrenders himself to a mass movement or to dogmatic beliefs in order to escape the responsibilities of freedom. A free society does not invite that kind of allegiance. It wants only one kind of devotion, the devotion of free, rational, responsible individuals." 4

In words that echo Ruth Anshen's conclusion that humans don't just use language but are the language they use, ${ }^{5}$ Frug argued that: "The postmodern position locating human

\footnotetext{
${ }^{3}$ For a not-very-flattering critique of postmodern scholarship see, Dennis W. Arrow, "Spaceball (Or, Not Everything That's Left is Postmodern)," 54 Vand. L. Rev. 2381 (2001).

${ }^{4}$ John W. Gardner, Excellence: Can We Be Equal and Excellent Too? 180 (Harper \& Row, N.Y. 1961).

5 Anshen, Language: An Enquiry into Its Meaning and Functions.
} 
experience as inescapably within language suggests that feminists should not overlook the constructive function of legal language as a critical frontier for feminist reforms. To put this "principle" more bluntly, legal discourse should be recognized as a site of political struggle over sex differences." 6

With this background and looked at strategically, it is easy to understand why some feminists, gender and sexuality and critical race scholars have spent so much time on anti-harassment policies, speech codes, and other efforts to create and define a new set of legally objectionable_-and therefore intimidating limitations on expression. ${ }^{7}$ It has been a powerful strategy and effective political weapon. In another culture and age it might be criticized as a form of thought control. Today it is celebrated by another "You go Girl!”

\section{The Example of John Silber's Epistemopathologies}

Ideas are weapons of great utility in weakening a dominant system and consolidating power. ${ }^{8}$ An irony is that once power is achieved, eliminating or co-opting the most skilled wielders of intellectual weapons prevents them from being turned on the system's new masters by naïve intellectuals who predictably recoil when it becomes clear that the "new" order they helped to create is as repressive as the orthodoxy it supplanted. But it also brings intellectuals into the service of the new ruling class as propagandists because at heart many intellectuals are cowards or seek power.

Former Boston University president John Silber described such behaviors as "epistemopathologies" or politically oriented intellectual movements within the university that he argued not only pursue their own political paths of action but simultaneously repress others' intellectual freedoms. ${ }^{9}$ One characteristic is that the movements brook no criticism, responding savagely to any challenge to their positions. The controversial Silber kindled a firestorm among those who consider themselves as

\footnotetext{
${ }^{6}$ Frug, "A Postmodern Feminist Legal Manifesto," at 1045. See also Fonow and Cook, Beyond Methodology, at 5.

7 “Activists have ... exploited exceptions to the First Amendment to silence voices counter to their ideology. And they have persuaded universities to impose drastic speech codes on students and faculty, turning institutions that were supposed to be bastions of free speech into enclaves of repressed speech. For example, the harassment policy of New York's Bard College forbids conduct that "causes embarrassment, discomfort, or injury to other individuals or the community.” In essence, the contrived right not to be offended is trumping the expressed right to free speech, the crown jewel of the Constitution. Instead of being places where even the most obnoxious ideas are dissected and debated, college campuses now are cloaked in self-imposed silence.” Detroit News, Tuesday, November 18, 2003, "Losing Liberty: First Amendment: Rules Stifling Free Speech Damage Democracy," http://www.detnews.com/2003/editorial/0311/18/a10-328173.htm.

${ }^{8}$ Daniel Bell, The End of Ideology 370-371 (New York 1960).

${ }_{9}^{9}$ Alice Dembner, "Silber says new theories can put limit on freedom," The Boston Globe, November 30, 1993, Metro/Region; Pg. 1. The dispute that exploded over John Silber's use of the term epistemopathologies is chronicled in Alice Dembner, "Silber defends record, calls faculty leader liar," The Boston Globe, December 1, 1993, Metro/Region; Pg. 1, and Alice Dembner, "Silber says new theories can put limit on freedom," The Boston Globe, November 30, 1993, Metro/Region; Pg. 1.
} 
part of the political Left. ${ }^{10}$ Silber was instantly excoriated for his remarks and labeled an intellectual bigot. The intensity and vehemence of the attacks on Silber ironically suggested that you are indeed defined by your enemies and that there was more than a grain of truth in his observations. To limit the impact it was necessary to isolate him through aggressive criticism and labeling and intimidate any who might share his views.

Some faculty leaders at Boston University were particularly concerned that Silber's remarks to university trustees "had contributed to a chilling climate that was affecting selection of research topics." 11 Silber responded that: “Resistance is a proper response to those who would illegitimately impose [their views] on others"” 12 He went on to say that " Boston University has resisted the imposition of doctrines that would curtail intellectual and academic freedom. It is plain that some versions [emphasis added] of critical theory, radical feminism and multiculturalism, among other intellectual positions, are ideological in character and inhospitable to free intellectual inquiry., ", 13

Silber faced allegations by the Boston University Faculty Council that he had created a climate of intellectual intimidation based on remarks that the university had remained "highly resistant to political correctness and ideological fads." 14 Silber included "critical legal studies, revisionist history, Afro-centrism, multiculturalism and radical feminism" in his criticism, stating that: "certain versions of radical feminism, multiculturalism, and other intellectual theories should be resisted because they are 'inhospitable to free intellectual inquiry.", 15

We traverse a minefield as we attempt to sort out the potential applications of Silber's position. On the one hand we have a university president saying he is trying to communicate about something he considers vital about the spirit of the university and is doing so to protect the freedom and authenticity of scholars' inquiry. ${ }^{16}$ On the other

10 “Boston University president John Silber ... angrily defended his record on academic freedom and called a faculty leader who raised the issue a coward." Dembner, "Silber says new theories can put limit on freedom," id.

${ }^{11}$ Dembner, "Silber says new theories can put limit on freedom,” id.

12 Dembner, "Silber says new theories can put limits on freedom," id.

${ }^{13}$ Dembner, "Silber says new theories can put limits on freedom," id.

14 Dembner, "Silber defends record," id.

15 "Silber defends record," id. The report added that: "Marxism was not included in Silber's earlier remarks as an area that had been 'resisted.' Those mentioned in the April 15 report to trustees were critical legal studies, revisionist history, Afro-centrism, radical feminism, multiculturalism, the Frankfurt School of Critical Theory, structuralism and deconstructionism, dance therapy, gay and lesbian liberation and animal liberation.” Id.

${ }^{16}$ Consider this example. Onorio, “The intolerance of tolerance,". Onorio asks: "What exactly is tolerance? What I've known the word to mean in an academic setting is a mutual respect for all ideas and all people, even if you disagree with them. The First Amendment guarantees the freedom of speech and it is the responsibility of everyone to respect this right." He then reports: "A recent incident down the street at the University of North Carolina seems to be another terrible demonstration of the intolerance of tolerance. In a "Literature and Cultural Diversity" course, a student found himself singled out by the instructor for hate speech, after the student said he opposed homosexuality. [The instructor] Elyse Crystall wrote in an e-mail to the class that the student was a perfect example of white privilege. She 
side we see university faculty who assert that rather than protecting intellectual freedom Silber's position generates a "chilling effect" that undermines the very spirit of intellectual freedom he claims to be protecting. So what is really occurring in the various camps when such positions are taken?

\section{Was John Silber Correct?}

Three decades later it is hard to deny that some aspects of the new critiques and movements fit within the "pathological" aspect of John Silber's fear of epistemopathologies in the sense that the strategy seeks to control the nature of others' discourse more than to present its own truths. ${ }^{17}$ How else can we assess such antiintellectual "events" as "triggers", "micro-aggressions”, “white privilege”, "white supremacy”, Islamophobia, homophobia and its subset lesbophobia? ${ }^{18}$

We no longer are committed to the concept that "knowledge is power" as opposed to one of "mind control is power" and that such control is achieved by shaping people and their behavior through language. Joseph Stalin and Adolph Hitler took the same approach. Central to their ability to control their people subject to their power was the creation of powerful propaganda machines that shaped their people's thought and action--or at least how they acted to avoid being crushed by the state's power.

The aim of the propagandist is to create "in-group" and "out-group" stereotypes that determine how we perceive, think and act. Done well and over time the successful propagandist shapes the identity of those under the "spell" of the linguistic "puppet master". Jacques Ellul, in his classic Propaganda explains: "A stereotype is a seeming value judgment, acquired by belonging to a group, without any intellectual labor.... The stereotype arises from feelings one has for one's own group, or against the "out-group." Man attaches himself passionately to the values represented by his group and rejects the cliches of the out-groups.... The stereotype ... helps man to avoid thinking, to take a personal position, to form his own opinion.” 19

Maxine Greene offered a powerful insight on the topic of propaganda and stereotypes and their impact on a society. In warning that slogans and propaganda have replaced intelligent dialogue Greene explains that slogans are "rallying symbols" that "in no sense describe what actually exists, yet they are taken-wishfully or desperately-to be generalizations or statements of fact." ${ }^{20}$ In such an environment legitimate criticism easily slides toward fanaticism, and many of the most important social disputes such as

claimed that the student used "hate speech" and it created a hostile environment in the classroom." But even that repression of discourse wasn't enough. "But Ms. Crystall didn't stop there. She referred to the student as "a white, heterosexual, [C]hristian male" who "can feel entitled to make violent, heterosexist comments and not feel marked or threatened or vulnerable.””

17 See "Silber defends record." Also consider the idea that: "Liberalism ... immediately denied freedom to those who disagreed with it." Johannes Hirschberger, A Short History of Western Philosophy 128 (1977).

18 See, Eric Hoffer, The True Believer: Thoughts on the Nature of Mass Movements (1951), and his discussion of how the "fault finding man of words" attacks a dominant orthodoxy in order to undermine its perceived legitimacy and hold on power. Id, at 120.

19 Jacques Ellul, Propaganda,

20 Maxine Greene, Teacher as Stranger 70. 
those over terrorism, race relations, Islam, immigration, abortion, gay marriage, and virtually any other critical social issue we can think of have drifted in some ways toward the extremes. Gabriel Marcel places what is occurring in a context of fanaticism, reminding us of the improbability of effective discourse. Marcel writes: "The first ... observation to be made is that the fanatic never sees himself as a fanatic; it is only the non-fanatic who can recognize him as a fanatic; so that when this judgment, or this accusation, is made the fanatic can always say that he is misunderstood and slandered.” 21

Honesty, in a situation such as the Silber imbroglio, requires that some scholars in the questioned disciplines admit that they are pursuing their preferred vision of society and that what is going on is power scholarship-not truth scholarship. It is an effort to reshape the culture by determining what is acceptable discourse and related behavior. As such, it seeks to engineer a certain kind of human and a specific kind of society. It is also a source of power because those who control the terms of discourse and define the allowable vocabulary and conceptual structure control the game.

In a political culture this is an admirable strategy for those seeking power or to defend what they possess because it creates the ability to preempt the field in which language is used. Granting the validity of Anshen's point that we are to a significant extent the language we use and Frug's recognition that power emanates from the ability to control language, being able to shape the allowable language increases the control over how we think, what we say, and how we act in certain contexts. But brilliant political strategies are likely to become insidious threats to honesty and to the pursuit of truth. In an intellectual community committed to independence and integrity such as has been claimed for education and journalism is dangerous and potentially destructive.

Frug at least was honest and transparent in her description of what she was advocating. She went on to say that: "This is not a proposal that we try to promote a benevolent and fixed meaning for sex differences.... Rather, the argument is that continuous interpretive struggles over the meaning of sex differences can have an impact on patriarchal legal power." 22 Some of the "interpretive struggles" have been designed to preempt the terms of discourse and to impose limits on speech. This is the language of political struggle, strategy and a war of attrition, not that of the detached and independent scholar. In fact one of the most prominent Crits now teaching at Harvard used the "war of attrition" description explanation when we are discussing the movement twenty years ago. As it was at that time, it remains a guerrilla war in which language is being used to "sap" and undermine the existing power structure.

A challenge to such control and a reemphasis of the importance of open discourse has been argued by Daphne Patai in the context of her challenge to the frequently voiced assertion that those who are from a subordinated class have the right to use offensive speech against other dominant groups, while members of those dominant (now

\footnotetext{
${ }^{21}$ Gabriel Marcel, Man Against Mass Society 136, 137 (1969).

${ }^{22}$ Mary Joe Frug, “A Postmodern Feminist Legal Manifesto (An Unfinished Draft)," Harvard Law Review 1045 (March, 1992).
} 
previously dominant) groups must be condemned if they ever use a disfavored term. She reports that: "[Harvey] Silverglate ... rejected the arguments of critical race theorists that offensive speech uttered by historically oppressed minorities should be protected, while comparable speech by their supposed oppressors can be suppressed. Academic freedom, he warned, cannot continue to exist with such a double standard." 23

Patai goes on to observe: "It seemed to me that the prevailing view was that curtailing free speech is acceptable if the objective is to make women and members of minority groups "comfortable" in the university. As Silverglate wrote to me after the [AAUP] conference: "All in all, my impression when I left was the same as it was when I arrived -- the control of speech and thought is well-advanced in the one place where it should be absent.' ", 24

\section{Multiculturalism and Increased Fragmentation}

It is fair to ask whether the criticisms of the new political scholarship are ones based on concerns about the quality of the work or if they reflect some more visceral reaction derived from a combination of politics, vested interests, and natural resistance to change. ${ }^{25}$ Martha Nussbaum suggests something of more importance for the university, arguing that: "Under the label "multiculturalism"--which can refer to the appropriate recognition of human diversity and cultural complexity--a new antihumanist view has sometimes emerged, one that celebrates difference in an uncritical way and denies the very possibility of common interests and understandings, even of dialogue and debate, that take place outside one's own group. .... This view denies the possibility of the task [Harlan] Ellison set himself: "of revealing the human universals hidden within the plight of one who was both black and American.” 26

This represents not only a refusal of discourse among humans but takes the position that it is not possible or desirable. This denial of the spirit of human development within intellectual and social community leads to a collapse of the idea of a shared quality that binds us in a common effort. The logical outcome is a devolution to a balkanized political and social condition resulting in an internecine struggle for control of the institutions of power-whether to use that power against others or to prevent it being used against you.

\footnotetext{
${ }^{23}$ Daphne Patai, "Speak Freely, Professor -- Within the Speech Code," Chronicle of Higher Education, June 9, 2000, pg. B7. See also, Patai, Heterophobia: Sexual Harassment and the Future of Feminism (Rowman \& Littlefield, 1998).

${ }^{24}$ Patai, "Within the Speech Code," $i d$.

25 Martha Nussbaum suggests that even with the current excesses of the postmoderns and multiculturalists the intellectual sky is not falling. She concludes: "Nor is it a cause for grave concern, ultimately, that many contemporary critics espouse forms of moral relativism deriving from French postmodernist philosophy, denying the objectivity of value judgments. One may certainly take issue with the conclusions of these critics, and find fault with their arguments. [In any event] philosophers thinking about truth and objectivity have not been very impressed by the arguments of the postmodernist critics....” Nussbaum, Cultivating Humanity, at 108.

${ }^{26}$ Nussbaum, Cultivating Humanity, id, at 110.
} 
Although Nussbaum's criticism of the distortion that some have made of multiculturalism is unfortunately accurate from the perspective of the lack of intellectual quality, balance and precision of much of the work, even the uncritical "critical" scholarship she decries may have important positive intellectual effects over time. If we look at what is occurring as a process and system rather than as individual episodes, even flawed work can generate an intelligible and intelligent reaction. Similarly, assertions may be individually assailable but the collection taken together can argue "large truths" and also offer the raw material of a cultural reality that can be usefully analyzed and critiqued.

Russell Jacoby also criticizes the application of the phenomenon of multiculturalism, observing: "The ideas of multiculturalism, cultural pluralism and diversity turn sacrosanct. They become blank checks payable to anyone in any amount, lacking meaning or content. They not only suggest a politics, but often replace politics. However, even with adjectives like radical or transformative attached, what politics do they designate? Apart from the wish to include more voices in the curriculum or different faces at the office, no vision drives multiculturalism. .... The rise of multiculturalism correlates with the decline of utopia, an index of the exhaustion of political thinking.” 27

Jacoby is right in that there has been a decline in the quality of political thinking, but fails to recognize that there has been an increase in the amount of political action and strategic behavior amid the use of propaganda to take control of sources of power. We have largely abandoned the pursuit of knowledge for itself and have replaced it with the application of knowledge to achieve desired results. Virtually everything we do has a specific end and we don't waste time on other pursuits. This includes the university world in which end results, grants, patents and so forth have become goals in themselves and determine the conditions under which rewards will be dispensed.

The telling counterpoint to Jacoby's argument is that multiculturalism is a political rather than an intellectual conception. It requires no vision because it is a strategy to acquire power for the groups asserting its issues and to limit the power of those who have traditionally possessed it and who are seen as responsible for previously silencing the interests represented within the multicultural perspective.

This means that multiculturalism is best understood as a political tool rather than an intellectual phenomenon, and the search for power is the most common element in an otherwise loose alliance of interests operating according to its rhetoric. The scholaractivists represent a kaleidoscope of divergent beliefs, goals and ideologies. Many of the collaborating collectives have little in common other than the need to fight what is perceived to be a common political enemy, i.e., those already entrenched in coveted positions of power and those who might question the legitimacy and agendas of the newly emergent movements.

\footnotetext{
${ }^{27}$ Jacoby, The End of Utopia: Politics and Culture in an Age of Apathy 33.
} 
Identity groups create formal and informal organizations. As they take form they inevitably define group agendas and "us" versus "them" perspectives take hold. This occurs because in a zero-sum world benefits flowing to newly created organizations represent benefits draining away from pre-existing organizations. In a world in which many of the most desirable employment opportunities are disappearing due to globalization, large scale mergers that eliminate entire tiers of management jobs, and production outsourcing of goods and services as well as automation and robotics that are combining to eliminate millions of positions relied on by an increasingly marginalized class of employees the competition to sustain opportunities for one's group and the resentment of those considered to have an unfair advantage only increases. If racial, ethnic and gender animosity is thought to be increasing "we ain't seen nothing yet”.

This marginalization of what had previously been a strong layer of the American middle class and blue-collar workers and the elimination of an enormous number of jobs even beyond those considerations has important consequences for the organizations and the overall political community within which they are operating. Robert Dahl describes the way organizational behavior not only defines us but limits our intellectual focus. He emphasizes: "Organizations ... are not mere relay stations that receive and send signals from their members about their interests. Organizations amplify the signals and generate new ones. Often they sharpen particularistic demands at the expense of broader needs, and short-run against long-run needs. .... Leaders therefore play down potential cleavages and conflicts among their own members and exaggerate the salience of conflicts with outsiders." 28

Dahl concludes: "Organizations ... strengthen both solidarity and division, cohesion and conflict; they reinforce solidarity among members and conflicts with nonmembers. Because associations help to fragment the concerns of citizens, interests that many citizens might share-latent ones perhaps_may be slighted.” 29 This sense of identity group solidarity and consequent divisiveness may be exacerbated in the context of the feminist movement - at least to the extent we believe some feminist's statements about the characteristics that tend to be found in women versus men. Women, we are told, instinctively tend to work together more than men. ${ }^{30}$ They tend, we are told, to have greater empathic abilities than male counterparts. They tend to be less competitive and more oriented toward community. ${ }^{31}$

${ }^{28}$ Dahl, Dilemmas of Pluralist Democracy: Autonomy vs. Control 44.

${ }^{29}$ Dahl, Dilemmas of Pluralist Democracy: Autonomy vs. Control 44.

${ }^{30}$ See, Fonow and Cook, Beyond Methodology.

${ }^{31}$ Helen Fisher, The First Sex: The Natural Talents of Women and How They Are Changing the World 4 (Random House 1999), argues: "I believe there are subtle differences in the ways that men and women, on average, organize their thoughts-variations that appear to stem from differences in brain structure." .... "Feminine thinking is even affecting our basic beliefs about justice, health, charity, leisure, intimacy, romance, and family." Fisher continues: "[W]omen, on average, take a broader perspective than men do-on any issue. Women think contextually, holistically. They also display more mental flexibility, apply more intuitive and imaginative judgments, and have a greater tendency to plan long term-other aspects of their contextual perspective. .... [W]omen's broad, contextual, holistic way of seeing will pervade every aspect of twenty-first-century economic and social life.” 
Generalities are inevitably dangerous and deceiving even if sometimes accurate in certain contexts. Even though I have known or worked with numerous women who were quite competitive and not necessarily interested in working or "playing well" with others I can see why such as description could be applicable to many. But when these "different tendencies" are turned around and looked at neutrally rather than as virtues, it is not unfair to speculate that, if the assertions are true as a general proposition (and this is not obvious) then it can be expected that women will behave differently as scholars than men.

Differences generate mystery and carve out a special fiefdom for those who fit within the specific quality defined as different while excluding from the new group those who do not possess the intrinsic characteristics defined as locating the new territory. The claim to difference is therefore a search for both power and identity. Women's tendency to work more collaboratively could easily mean that women are less likely to criticize each other as aggressively as men.

It could mean that women feel more comfortable operating as part of a collective movement and are less likely to be willing to create conflict with their peers. The question to be asked is what are the implications of these alleged differences? If honest critique of other scholars' positions is an essential element of a scholarly community, are members of a particular collective able to properly evaluate the work of others within that collective or is there a veiled "pulling of the punches" that allows substandard work to be approved or even praised? My point is simply that we should take assertions about women's (or men's) natural qualities with a grain of salt regardless of who utters the proclamation.

Even if the points raised here are valid what difference does it make? Certainly there are many good reasons why university-based activists are justified in manipulating the existing system to obtain benefits that were wrongly denied due to gender, class and racial bias. Those who claim to be committed to the pursuit of pure knowledge and truth far too often have a history of conveniently ignoring the bias, exclusion and discrimination that existed with their institutions and disciplines.

\section{The Death of Liberalism}

Universities in many ways can be said to deserve being taken over by the guerrilla forces of women and minorities who have unquestionably converted a substantial piece of the institution to their interests and control. Yet even as I write these words I wonder about damage to the very ideal of truth-an ideal I still consider to be a fundamental beacon-and often feel uncomfortable with the "knee jerk" expectation that dominates academia that there is an agreed-on set of consciously Left agendas to which everyone is assumed to subscribe or at least support.

It is not that I am opposed to many of the agendas in terms of principle or even operational reality but that I have an absolute distrust of singular controlling 
orthodoxies, however defined. Orthodoxy equals power and as we noted with Acton's warning, power always corrupts no matter who occupies its throne and controls its levers. Peter Berger describes the repressive subtleties of controlling orthodoxies. "Very potent and simultaneously very subtle mechanisms of control are constantly brought to bear upon the actual or potential deviant. These are the mechanisms of persuasion, ridicule, gossip and opprobrium.” 32

Oddly enough modern Liberals seem intent on destroying the values of the very society that allowed them to exist. There is an atmosphere breathed by modern academics and activists for that matter-particularly in the noncumulative non-empirical disciplinesthat believes that anything said by an identifiable member of a group that had previously been a target of discrimination was automatically true and that those who are not full-fledged members of that group can question any aspect of the proffered "truth" only at great peril. In that sense, it means that I can not truly understand the core of any other identity group even though, apparently, they can fully comprehend everything about those not of their identity and critique the thoughts, language and actions of those.

I do not share this perspective. In fact, I find the words of Chairman Mao relevant to this topic. In discussing the fate of Liberalism in a revolutionary setting he observed:

Liberalism is extremely harmful in a revolutionary collective. It is a corrosive which eats away unity, undermines cohesion, causes apathy and creates dissension. It robs the revolutionary ranks of compact organization and strict discipline, prevents policies from being carried through and alienates the Party organizations from the masses which the Party leads. It is an extremely bad tendency. ${ }^{33}$

Control of the language of discourse not only provides the concepts that can be used but inhibits the use of disfavored concepts. In a political community this is an inevitable and in some ways even desirable process when applied with sophistication and dexterity. Of course we generally fail in that and default to clumsiness and overreaching. The question to be answered is the degree to which this kind of control is desirable or appropriate in the university, or whether universities have a duty not only to the immediate society but to honor the past and prepare for the future.

\footnotetext{
32 Peter Berger, Invitation to Sociology: A Humanistic Perspective 93 (1963).

33 “Combat Liberalism" (September 7, 1937), Selected Works, Vol. II, p. 32.https://www.marxists.org/reference/archive/mao/works/red-book/ch24.htm.
} 